\title{
Music, Melancholia, and Mania: Gaetano Brunetti's Obsessional Symphony
}

\author{
PETER PESIC
}

Obsession may be the besetting disorder of modern consciousness, if not its hallmark. During the nineteenth century, monomania became the most frequently diagnosed form of mental illness. For instance, during the period 1826-33, 45 percent of the inmates at the Charenton asylum in Paris were diagnosed with various forms of monomania, according to Jean-Étienne Dominque Esquirol (1772-1840), the French physician who coined this term and brought it to wide awareness. Later known as idée fixe, monomania generally corresponded to what in the following century came to be called obsessional neurosis (Freud), then obsessive-

\footnotetext{
I thank David Trippett for his many helpful comments and suggestions as well as for inviting me to present this material at his 2017 conference "After Idealism: Sound as Matter and Medium in the 19th Century" at the Centre for Research in the Arts, Social Sciences and Humanities, University of Cambridge, where I profited from many thoughtful comments by the participants. My thanks also to Guillermo Bleichmar for help with the nuances of Spanish vocabulary and usage. Please see the online version of the journal to listen to examples.
}

compulsive disorder (in contemporary psychiatry). ${ }^{1}$ Contextualizing Hector Berlioz's use of a musical idée fixe in his Symphonie fantastique, scholars commonly mention Gaetano Brunetti as first having used the musical technique of idée fixe in an unusual program symphony. ${ }^{2}$ Though there has been some attention to this composition, I would like to offer a detailed analysis of Brunetti's symphony that brings forward the richness and novelty of his somewhat subversive take on the musical style of his time in the context of the disturbed conditions familiar to him among his own patrons in the royal Spanish court. ${ }^{3}$ This context is

\footnotetext{
${ }^{1}$ For an overview of the phenomenology of obsession, see Lennard J. Davis, Obsession: A History (Chicago: University of Chicago Press, 2008), 3-30.

${ }^{2}$ Francesca Brittan, "Berlioz and the Pathological Fantastic: Melancholy, Monomania, and Romantic Autobiography," this journal 29 (2006): 211-39, who acknowledges Ralph Locke for this information (214n.14).

${ }^{3}$ The most detailed treatment to date is Blake Howe, "Music and the Agents of Obsession," Music Theory Spectrum 38 (2017): 218-40. See also Virginia Georgallas, "The Maniac's Affliction: Music, Madness, and Caprice in Late EighteenthCentury Spain" (AMS/SMT Conference, Vancouver, BC,
} 
further illuminated through Don Quixote as an omnipresent figure in Spanish literature, probably the most famous madman in world literature, an inescapable example for later accounts of obsession, both literary and medical.

Brunetti's symphony has a special place in considering what I have called a "sonic turn" in medicine, meaning the increased use of sound and music to probe aspects of body and mind that go beyond what is available to the "medical gaze." ${ }^{4}$ In contrast to the political dangers of discussing the varieties of royal insanity verbally, Brunetti's musical depiction of obsession (as we would call it) could be direct and detailed with less risk of incurring royal ire. As we will see, Brunetti evoked not only the static outward signs of mania through the mannerisms of a solo cello but also the dynamic interaction between the solo cello as "maniac" and the surrounding "normal" world, portrayed by the rest of the orchestra. He presents the different stages of their interaction with wit and sympathy in ways that might well have had special significance for his royal patron, soon to become Carlos IV, who had grown up with the maladies of his elders. Yet this work goes beyond a mere symphonie à clef because Brunetti ultimately turns the tables on the "normalcy" of contemporary music to reveal obsessional elements throughout the elegant surface of classical style. In a dénouement that recalls similar reversals of perspective in contemporary Spanish dramas, Brunetti discloses unsettling resemblances between "sanity" and "madness." In so doing, he gave musical treatment in a new way to themes that had become famous in works like Don Quixote.

I begin by reviewing the generational succession of mental maladies in the Spanish royal house and the contemporary vocabulary for such conditions. After situating Brunetti in the context of the court (along with his colleague, Luigi Boccherini), I analyze Brunetti's symphony in light of its explicit program.

2016), whom I thank for kindly sending me a copy of this unpublished presentation and of the Piquer Discorso.

${ }^{4}$ Peter Pesic, "Music, Mechanism, and the 'Sonic Turn' in Physical Diagnosis," Journal of the History of Medicine and Allied Sciences 71 (2016): 144-72.
Finally, I compare Brunetti's insights to subsequent changes in the lexicon of alienism, especially the development of the concepts of idée fixe and monomania, arguing that literary and musical works began the investigation of obsession in ways only later reflected in medical analyses.

\section{Mania, Melancholia, and Obsession}

From the traditional meanings of various terms for insanity emerged the new developments I will discuss concerning "mania" and "melancholy." According to one standard medical text, Philip Barrough's The methode of phisicke (London, 1583), "Mania in Greeke is a disease which the Latines do call Insania and furor," characterized by "furiousnes" and behavior that is "unruly like wild beastes. It differeth from the frenesie, because in that there is a fever. But Mania commeth without a feaver. It is caused of much bloud, blowing up to the braine.." ${ }^{5}$ Short of the "furious madnes" of mania, melancholy "is an alienation of the mind troubling reason, and waxing foolish, so that one is almost beside him self. ... The most common signes be fearfulnes, sadnes, hatred, and also they that be melancholious, have straunge imaginations, for some think them selves brute beasts. . . . Moreover, they desire death, do verie often behight and determine to kill them selves.." ${ }^{6}$ The standard remedies were sleep, exercise, "moderate carnall copulation," and "delectations of the mind," especially to "heare musical instruments and singing." ${ }^{7}$ Other accounts, however, noted that the wrong kind of music could cause rather than cure such maladies. ${ }^{8}$

Barrough's text was widely reprinted until 1652. After that, the picture became more complicated. Thomas Willis, who coined the word "Neurologie," gave one of the most extensive accounts of mental illness in Pathologiae cerebri (1667) and De anima brutorum (1672). Willis

\footnotetext{
${ }^{5}$ Three Hundred Years of Psychiatry, 1535-1860: A History Presented in Selected English Texts, ed. Richard Hunter and Ida Macalpine (London: Oxford University Press, 1963), 27. ${ }^{6}$ Ibid., 27-28.

${ }^{7}$ Ibid., 28.

${ }^{8}$ See, for instance, Hunter and Macalpine, Three Hundred Years of Psychiatry, 377-78.
} 
turned from explanations of mental conditions in terms of humors (or of the uterus, in the case of hysteria) instead to the influence of "the Brain and Nervous Stock. ${ }^{\prime \prime}{ }^{9} \mathrm{He}$ attributed melancholy to "the passion of the heart," mania to "vice or fault of the Brain. ${ }^{10}$ Further, Willis considered these to be related, for "Melancholy being a long time protracted, passes oftentimes into Stupidity, or Foolishness, and sometimes also into Madness [mania]." ${ }^{\prime 11}$ Indeed, melancholy and mania "are so much akin, that these Distempers often change, and pass from one into the other; for the Melancholick disposition growing worse, brings on Fury; and Fury or Madness [mania] growing less hot, oftentimes ends in a Melancholick disposition. These two, like smoke and flame, mutually receive and give place one to another." ${ }^{\prime 2}$ I will shortly return to this connection as it was theorized in Spanish medicine.

In contrast, what later came to be called obsession, monomania, or idée fixe first was described in religious contexts, then more broadly, though without clear identification in the classical medical terminology of mania or melancholy. Religious texts from the 1500s address "scruples," repetitive thoughts that are "a great trouble of minde proceeding from a little motive," as Jeremy Taylor put it in Ductor dubitantium, or the rule of conscience (London, 1660), referring to the meaning of scruple as a tiny weight that nevertheless can lead to "a sad plight": "Some persons dare not eat for fear of gluttony, they fear that they shall sleep too much, and that keeps them waking." ${ }^{13}$ Indeed,

\footnotetext{
${ }^{9}$ Ibid., 187. See M. J. Eadie, "A Pathology of the Animal Spirits-the Clinical Neurology of Thomas Willis (1621-1675 Part I-Background, and Disorders of Intrinsically Normal Animal Spirits," Journal of Clinical Neuroscience 10 (2003): 14-29; M. J. Eadie, "A Pathology of the Animal Spirits-the Clinical Neurology of Thomas Willis (1621-1675) Part IIDisorders of Intrinsically Abnormal Animal Spirits," Journal of Clinical Neuroscience 10 (2003): 146-57.

${ }^{10}$ Hunter and Macalpine, Three Hundred Years of Psychiatry, 188. See Thomas Willis, De anima brutorum quae hominis vitalis ac sensitiva est, exercitationes duae (Amsterdam: Apud Joannem à Someren, 1674). "Mania" was translated as "madness" in Thomas Willis, Two Discourses Concerning the Soul of Brutes, trans. S. Pordage (London: Thomas Dring, 1683).

${ }^{11}$ Willis, Two Discourses, 193.

${ }^{12}$ Ibid., 201.

${ }^{13}$ Hunter and Macalpine, Three Hundred Years of Psychiatry, 163. See the historical survey in G. E. Berrios, The History of
}

since the sixteenth century obsessio specifically meant being besieged by the devil, an exacerbated form of fascinatio, the diabolic "fastening" of the mind. ${ }^{14}$ The term superstitio also was used to describe various forms of obsession or compulsion, such as what James Boswell called Samuel Johnson's "superstitious habit" of counting his steps. ${ }^{15}$ By the eighteenth century, though, obsession became the province of physicians, rather than clerics; unitary explanations in terms of diseased organs or ill-mixed humors gave way to a notion of "nervousness" that could manifest itself in more complex mixtures of rationality and obsession. ${ }^{16}$ There was no general clinical term for such involuntarily recurring thoughts or actions until the descriptions of idée fixe that I will consider and of monomania by Esquirol and others in the nineteenth century. Decades before that, though, Brunetti applied the term manía to such behavior via a musical evocation of obsessional mental states and their changing relation to the surrounding social milieu.

After the seventeenth century, the terminology of the Romance languages regarding madness changed significantly. Though manie is found in French dictionaries as early as 1606 (glossed as "Fureur, Mania, Furor"), El Ingenioso Hidalgo Don Quijote de La Mancha (whose parts first appeared in 1605 and 1615) described himself as loco; the term mania never appears in the book, only locura. ${ }^{17}$ Thereafter, Don Quixote loomed large as the most famous "madman"-obsessed with chivalry-in European literature, only Prince Hamlet having comparable significance and fame. ${ }^{18}$ To be sure, Cervantes left much ambiguity in his descriptions of Quixote as "a man whose power of reasoning is weak [hombre de flacos discursos]" or having "no judgment

Mental Symptoms: Descriptive Psychopathology since the Nineteenth Century (Cambridge: Cambridge University Press, 1996), 140-56, on 140-41.

${ }^{14}$ Berrios, The History of Mental Symptoms, 142.

${ }^{15}$ Ibid., 141.

${ }^{16}$ For an overview of these developments, see Davis, Obsession, 32-54.

${ }^{17}$ "Yo fuíl loco, y ya soy cuerdo"; Miguel de Cervantes, El ingenioso hidalgo Don Quijote de la Mancha, ed. Américo Castro, 19th edn. (Mexico City: Editorial Porrúa, 1979), 668. See La lengua de Cervantes, gramática y diccionario de la lengua castellana en el Ingenioso Hidalgo Don Quijote de la Mancha, ed. Julio Cejador y Frauca (Madrid: Ratés, 1905), 695. ${ }^{18}$ For obsession in other literary works, see Davis, Obsession, 54-65. 
at all [de ningún juicio]." ${ }^{19}$ Much turns on the understanding of mental conditions and its changing vocabulary. For instance, Spanish dictionaries did not include manía until the first edition of the Diccionario de la lengua castellana (1726-39) as a synonym of locura: "infirmity of the imagination [phantasia] that alters and disorders it, fixing it on a species [especie] without reason or foundation. ... Also signifies extravagance or caprice." Here, especie signifies an "image or idea of an object that is represented in the soul. ${ }^{\prime 20}$

Already in 1694, French dictionaries included manie as a heightened form of folie or fureur, such as tulipomanie, the craze for tulips that began in the Netherlands but spread throughout Europe. ${ }^{21}$ Still, manie was not used to denote pathological obsession until the fourth (1762) edition of the Dictionnaire de l'Académie française: "Manie is an insanity [folie] in which the imagination is struck by a fixed point. [Example:] The madness of one who believes himself to be made of glass was a fixed point. ... Said also by extension of all the passions carried to a certain excess," again instancing tulipomania. ${ }^{22}$ Thus, the usage of manía as obsessional fixation (as opposed to a social craze) seems to appear in Spanish usage decades before French. In any event, the use of manía as obsession preceded by decades the 1780 symphony I will consider, which arguably was thus reflecting this new usage of this word.

\section{Music and Madness in Spain}

Brunetti's symphony addressed a Spanish court with a long history of mental maladies. Felipe V (1683-1746), grandson of Louis XIV, ascended

\footnotetext{
${ }^{19}$ Cervantes, Don Quijote, 147.

${ }^{20}$ (Madrid: en la imprenta de Francisco del Hierro, impressor de la Real Academia Española, 1726-39|, 6 vols.

${ }^{21}$ See Anne Goldgar, Tulipmania: Money, Honor, and Knowledge in the Dutch Golden Age (Chicago: University of Chicago Press, 2008); Mike Dash, Tulipomania: The Story of the World's Most Coveted Flower et the Extraordinary Passions It Aroused (New York: Three Rivers Press, 1999).

${ }^{22}$ The second edition (1718) includes only maniaque as "furieux, possedé de quelque manie" $(2: 21)$. The third edition (1740) defines manie as "délire, aliénation de l'esprit sans fièvre, \& qui va jusques à la fureur. Sa folie se change en manie. Se dit aussi par extension, de toute les passions portées à un certain excès. Sa manie pour les tulippes, pour les coquilles, l'a ruiné" (II, 76).
}

the Spanish throne in 1700 as its first Bourbon monarch. Contemporary observers reported that Felipe V was prone to "black fits," terror, and bouts of melancholy. ${ }^{23}$ In constant mental crisis throughout his forty-six-year reign, he would bite his arms and legs, stay in bed for days, and refuse to cut his hair; for a time, he believed that he was a frog, among numerous other symptoms. ${ }^{24}$ To address the king's alarming mental instability, in 1737 the queen summoned the famous castrato Farinelli (born Carlo Broschi) in the hope that his singing might calm the monarch. According to a contemporary report, the queen had "arranged a concert in an apartment adjoining to that where the king was in bed, where he had lain for a considerable time; and from which no persuasion could induce him to rise. Philip was struck with the first air sung by Farinelli, and at the conclusion of the second, sent for him, loaded him with praises, and promised to grant him whatever he should demand." 25

Farinelli thereafter sang nightly for the king, whose mental stability seemed to depend on hearing this music, often howling for hours on end in imitation of his chosen singer. ${ }^{26}$ Thus, Farinelli ascended to incomparable influence at court, which continued during the succeeding reign of Fernando VI (r. 1746-59). Though far more stable mentally than his father, Fernando VI was also given to bouts of melancholy, which he too assuaged with Farinelli's singing; music and shooting, he said, were his only pleasures. His wife, Maria Barbara, was the patroness of Domenico Scarlatti, who had come to the Spanish court in 1731 as her music master and remained until his death in 1757. Maria Barbara's long and close association with Scarlatti and his sonatas added an additional depth of musical involvement to the

\footnotetext{
${ }^{23}$ Henry Kamen, Philip V of Spain: The King Who Reigned Twice (New Haven: Yale University Press, 2001), 121-24, 159-60, 162-63, 178-79, 189-91. For the larger context of Felipe V's disordered predecessor Carlos II see Vivian Green, The Madness of Kings: Personal Trauma and the Fate of Nations (New York: St. Martin's Press, 1993), 153-75.

${ }^{24}$ For his frog delusion, see Kamen, Philip V, 165.

${ }^{25}$ William Coxe, Memoirs of the Kings of Spain of the House of Bourbon, from the Accession of Philip V to the Death of Charles III: 1700 to 1788, vol. 3 (London: Longman, Hurst, Rees, Orme and Brown, 18131, 89.

${ }^{26}$ Kamen, Philip V, 200-02; Green, The Madness of Kings, 173; Ralph Kirkpatrick, Domenico Scarlatti (Princeton, NJ: Princeton University Press, 1953|, 94-106.
} 
Spanish court. ${ }^{27}$ Her death in 1758 left Fernando prostrate; during the remaining year of his life, he would not even dress but wandered about in his nightgown unwashed and unshaven.

More than a half century of royal madness led to much perplexity. In 1759 the court physician Andrés Piquer y Arrufat gave a detailed case history of Fernando's condition, which he described by the novel term "melancholicmanic illness [affectio melancholico-manaíca]. Melancholia and mania, although treated in many medical books separately, are the same disease. ${ }^{\prime 28}$ Here, he seems to have gone beyond Willis's position that melancholy and mania are merely "related." ${ }^{29}$ Thus, some modern scholars credit Piquer with describing the disorder later known as manic-depressive insanity (now called bipolar disorder) almost a century before Jean-Pierre Falret and Jules Baillarger described what they respectively called folie circulaire and folie à double-forme (1854). ${ }^{30}$

The childless Fernando was succeeded by his half-brother Carlos III (r. 1759-88), a man of some intelligence who became "the perfect type of the benevolent despot of the eighteenth century thoroughly imbued with the ideas of the French Encyclopaedists ..., one of the best, greatest, and most patriotic monarchs that Spain has ever known. ${ }^{\prime 31}$ In contrast to his predecessors, Carlos III was pointedly uninterested in music, though he built in Naples one of the largest contemporary opera houses. His punctilious adherence to schedule led him to carry out his public functions always at the same hour with great precision, invariably eating the same things at

\footnotetext{
${ }^{27}$ See Kirkpatrick, Domenico Scarlatti, 87-92, 107-36.

${ }^{28}$ Andrés Piquer, "Discurso sobre la enfermedad del Rey Nuestro Señor Don Fernando VI, que Dios guarde" (1759), Biblioteca Nacional de España, as translated in Jesús Pérez et al., "Andrés Piquer-Arrufat (1711-1772): Contributions of an Eighteenth-Century Spanish Physician to the Concept of Manic-Depressive Illness," Harvard Review of Psychiatry 19 (2011): 68-77, on 68, which gives a helpful analysis of Piquer's work.

${ }^{29}$ His later textbook Andrés Piquer, Praxis medica: ad usum Scholae Valantinae (Madrid: Ediciones Joachim Ibarra 1764), 94-95, cites Willis's De febribus (1659) but not Willis's work on mental conditions, which he does not seem to have known.

${ }^{30}$ According to Pérez et al., "Andres Piquer-Arrufat," 73, 74.

${ }^{31}$ Charles Petrie, King Charles III of Spain: An Enlightened Despot (New York: J. Day Co., 1971), 3, 229.
}

the same times of day. To mitigate his tendency toward melancholy, he pursued hunting with a comparable kind of obsessiveness; not long before his death he told a foreign ambassador that he personally had killed exactly 539 wolves and 5,232 foxes. ${ }^{32}$ Carlos III's own melancholy and obsessive hunting did not keep him from exercising his duties but he barred his eldest son Felipe from the succession on grounds of "imbecility": Felipe had to be restrained from his violent erotic tendencies, not to speak of his penchant for putting up to sixteen gloves (each larger than the one before) on one hand. ${ }^{33}$ As Piquer's work showed, contemporary Spanish medical discourse struggled to find new concepts and vocabulary for these perplexing (and ominous) royal maladies. ${ }^{34}$

Though himself unassuming, hard-working, and competent, Carlos III could hardly conceal his contempt for his younger son and designated successor Carlos (IV), "a good-natured man with a fair memory, and he was nowise deficient in judgment once his interest had been aroused, but his development was what is known as somewhat 'arrested'." ${ }^{35}$ His father told him he was a "complete fool" for naively believing that his wife would never become amorously involved with men of "inferior rank," as in fact she $\operatorname{did}^{36}{ }^{36}$ Exceedingly fond of hunting and a great collector of clocks, Carlos IV preferred the company of grooms to courtiers, practiced carpentry, advanced Goya to painter-in-ordinary at the court, and was extremely fond of music,

\footnotetext{
${ }^{32}$ For his melancholy, see W. N. Hargreaves-Mawdsley, Eighteenth-Century Spain, 1700-1788: A Political, Diplomatic and Institutional History (Totowa, NJ: Rowman and Littlefield, 1979), 100. For his remark to the ambassador, see Petrie, King Charles III, 228, 164-65.

${ }^{33}$ Petrie, King Charles III, 164-65.

${ }^{34}$ For the larger context, see Johann Baptist Ullersperger, Die Geschichte der Psychologie und der Psychiatrik in Spanien von des ältesten Zeiten bis zur Gegenwart (Würzburg: Stuber, 1871); Raquel Alvarez and C. M. Winston, "The History of Psychiatry in Spain," History of Psychiatry 2 (1991): 303-13.

${ }^{35}$ Petrie, King Charles III, 223-24. As king, Carlos IV was "good-hearted but weak and simple-minded ... vacillating and confused," his "ineptitude" leading directly to the fall of the Bourbon dynasty and the Napoleonic takeover in 1808, according to Stanley G. Payne, A History of Spain and Portugal (Madison: University of Wisconsin Press, 1973), 415-16, 420.

${ }^{36}$ Petrie, King Charles III, 226-27.
} 
playing the violin especially in string quartets, his favorite genre. ${ }^{37}$

In 1767, when the nineteen-year-old Carlos was prince of Asturias and heir designate, Gaetano Brunetti (then twenty-three) joined the court as his violin teacher. Born in Naples, Prince Carlos never mastered Spanish; his court remained basically Italian, and the prince surrounded himself with Italians such as Brunetti. ${ }^{38}$ Already by the time he came to Spain in 1759, at his father's accession to the throne, Prince Carlos had "an excellent knowledge and appreciation of musical technique. He was perhaps not exempt from a certain boastful arrogance, for he was a violinist himself." ${ }^{\prime 39}$ Brunetti had studied with Pietro Nardini; for his royal pupil he wrote pieces of considerable difficulty, indicating the prince's level of skill. ${ }^{40}$ In subsequent years, Brunetti continued to teach Prince Carlos while steadily advancing in rank among the royal musicians, in 1770 becoming director of music for various court festivals, thereby "reach [ing] the highest office and position that any musician at the court could hope to obtain. ${ }^{\prime 41}$

The years after 1776 brought considerable political stress and controversy as Spain contemplated how to respond to the American Revolution, facing "the dilemma of taking an imperial power into an anti-colonial war by pursuing exclusively Spanish interests without allying directly with the United States and without recognizing American independence. ${ }^{\prime 42}$ Allied with France, Spain then engaged in a war with Britain (1779-83). During this period, Prince Carlos became embroiled in various court intrigues that pitted him against his father, "who had kept him poorly educated, confined to childish

\footnotetext{
${ }^{37}$ Ibid., 224.

${ }^{38}$ Alice Bunzl Belgray, Gaetano Brunetti: An Exploratory Bio-Bibliographical Study (PhD diss., University of Michigan, 1970), 20.

${ }^{39}$ Juan Antonio Ruiz Casaux y López de Carvajal, La música en la corte de don Carlos IV y su influencia en la vida musical española (Madrid: Real Academia de Bellas Artes de San Fernando, 1959), 16. Cited and translated in Belgray, Gaetano Brunetti, 26.

${ }^{40}$ Belgray, Gaetano Brunetti, 83. According to Belgray,

"Brunetti also became acquainted with a vast quantity of

Baroque music, especially that written for the violin, both when he was a student of Nardini and in his earlier musical training" (113).

${ }^{41}$ Ibid., 87-88, 93.

${ }^{42}$ Ibid., 320.
}

amusements, trusted with nothing, and debarred from even the appearance of doing business." ${ }^{\prime 43}$ At cabinet meetings he became so outspoken advocating views that opposed the king's that Carlos III directly warned him that "if it is thought that division exists now between father and son, then there will certainly be people in the future who will suggest to your family to do exactly the same to you. ${ }^{\prime 44}$ The underlying tension between the obsessive king and his rebellious son formed one of the subtexts of the music I will now consider.

\section{Brunetti's Symphony "Il MANiÁtico"}

Such, then, was the tense political and dynastic situation in 1780 when Brunetti introduced his Symphony No. 33, subtitled in the manuscript score "Il Maniático" (The Maniac). Like all his works composed at court, this symphony was designated solely for Prince Carlos's use and implicitly dedicated to him so that its peculiarities should therefore be read within this context; Brunetti never traveled abroad and the circulation of any of his works outside the court would have required special permission lest it fall afoul of the royal administration or even of the Inquisition. Thus, this symphony remained unpublished until the twentieth century. ${ }^{45}$ What, then, was the significance of Brunetti's depiction of a maniático, that is, one suffering from manía? Though Brunetti wrote his own explicit program in the score presented to the prince, I will examine it against the primary evidence of the music itself and contemporary understandings of manía. The following analysis, then, explores a programmatic reading of the score in relation to its written program and its peculiar medical context, drawing in particular on schemes of representation and mimesis to assign narrative value to the instrumental score.

\footnotetext{
${ }^{43}$ John Lynch, Bourbon Spain 1700-1808 (Oxford: Basil Blackwell, 1989|, 294.

${ }^{44}$ Ibid., 295.

${ }^{45}$ Newell Jenkins rediscovered and recorded it, published as Gaetano Brunetti, Il "maniático": Sinfonia no. 33 [e] Sinfonia in sol min., no. 22, ed. Newell Jenkins (Roma: L. del Turco, 1960).
} 


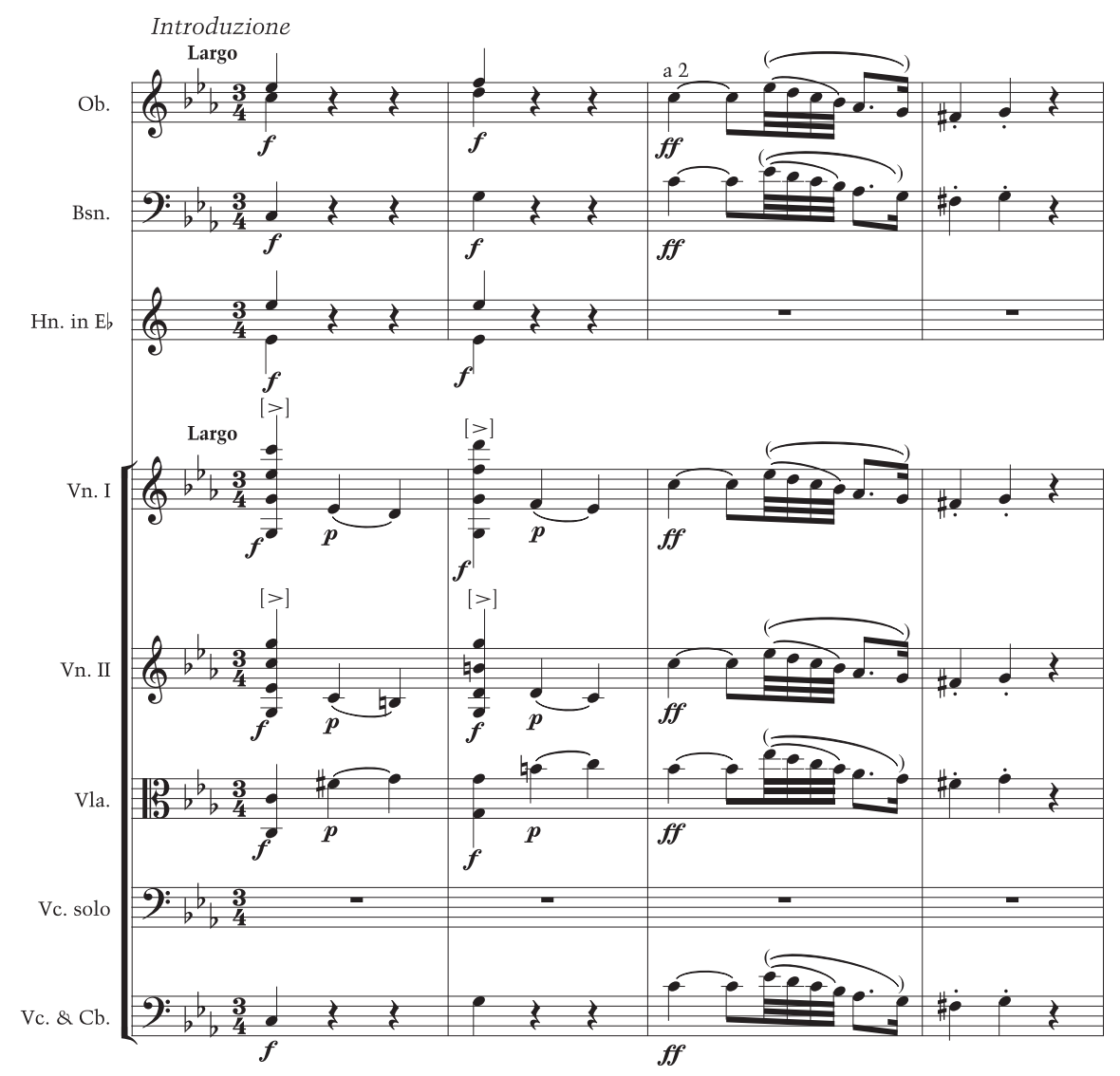

Example 1: Gaetano Brunetti's Symphony No. 33, the beginning of the first movement.

The symphony begins with an extended introduction in C minor, marked "Largo," in a serious, almost tragic style. Peremptory forte chords of the full orchestra alternate with softer statements from the strings, beginning with a sighing semitonal motif show in ex. 1, seemingly a gesture of lamentation. The introduction continues in that vein, adding arresting unison statements fortissimo, abrupt silences, and other hallmarks of the "sensitive style" (empfindsamer Stil)..$^{46}$ Indeed, such introductions also were found in the symphonies of Joseph Haydn, generally taken to have been the exemplar whom Brunetti followed. ${ }^{47}$ Normally, a slow introduction would lead to an allegro; instead, after a

\footnotetext{
${ }^{46}$ See Matthew Head, "Fantasia and Sensibility," in The Oxford Handbook of Topic Theory, ed. Danuta Mirka (New York: Oxford University Press, 2014), 259-78.

${ }^{47}$ See Rene M. Ramos, The Symphonies of Gaetano Brunetti (ca. 1744-1798) (PhD diss., Indiana University, 1997), 304-18.
}

fermata on the dominant the strings put on their mutes and begin another slow movement, marked "Andantino," with a rather dreamy pianissimo phrase, still in $\mathrm{C}$ minor and in the prevalent mood of sadness, ending with a sighing semitone. At this point, a solo cello enters, indicated in the score just above the other celli and basses, his line marked Manía. Here, then, is the maniático, who merely repeats a semitone in pensive thirty-second notes on the dominant (G-F\#; ex. 2). ${ }^{48}$ It seems likely that Brunetti would have known the Spanish court poet Tomás de Iriarte y Oropesa (1750-91), whose didactic poem La Música had appeared the year before (1779) and who described the semitone as "primordial": "Let him o'er whom or tears

\footnotetext{
${ }^{48}$ The immediate cause seems to be the semitone $\mathrm{Eb}-\mathrm{D}$ in the first violins (m. 20), but the Largo had ended with an extended G-F\# trill in the first oboe (mm. 17-19).
} 


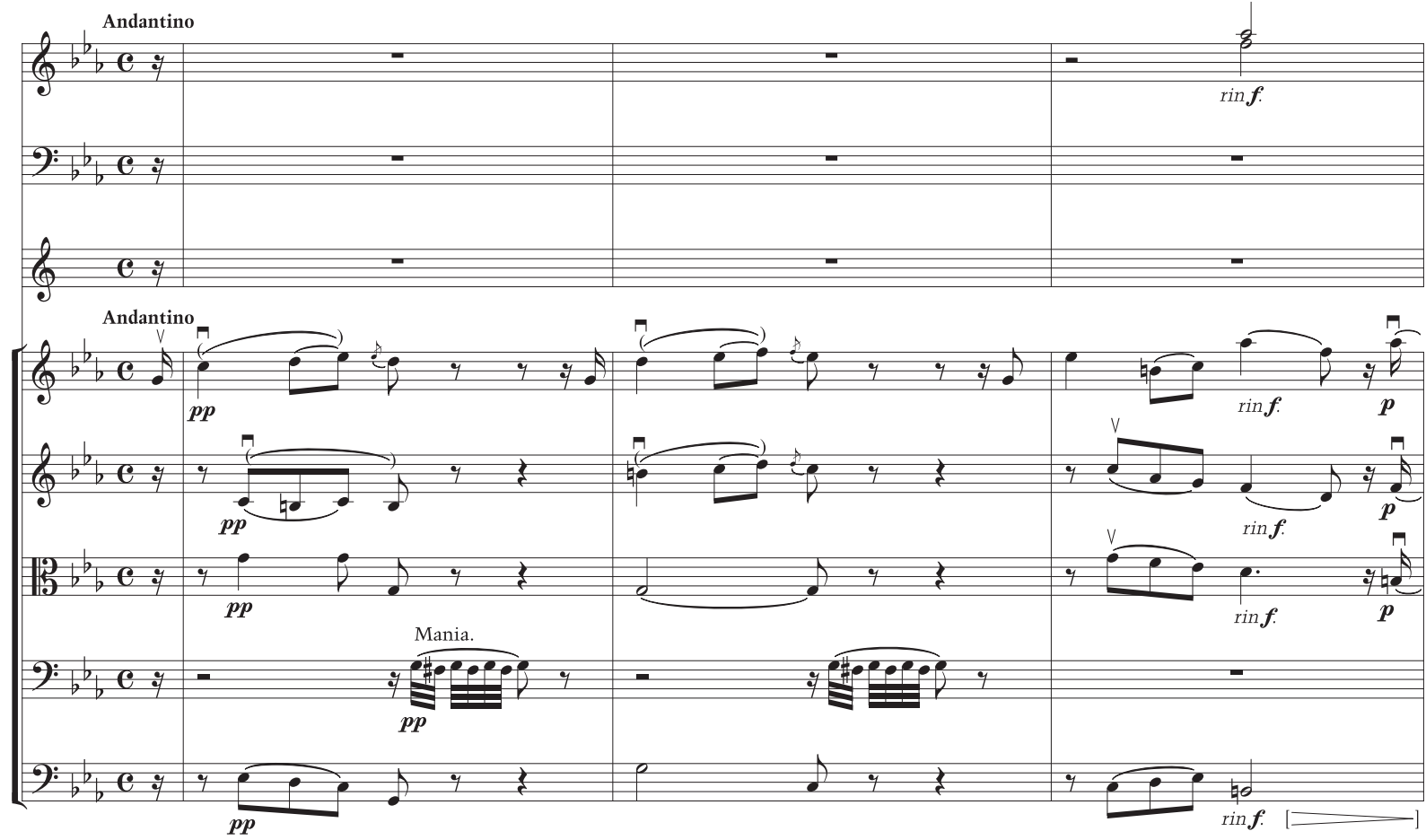

Example 2: The first three measures of the Andantino, showing the first statement of manía.

or fears prevail, / Study the tones of the chromatic scale," noting that semitones belong to sad emotion and anguish, "Moanings and groans that speak unnumbered woes, / And death's last agonies." ${ }^{49}$ In Brunetti's symphony, the orchestra's melancholy semitones seem to be the trigger for the manía. In the following passage, though the maniático repeats this semitone gesture in its initial form, he then transposes it quite appropriately within the larger harmonic context of the orchestra.

Let us pause over Brunetti's terminology. As noted above, earlier texts did not use manía to describe such repetitive ideas, for which there seemed to have been no established term. As a servant of the court, it seems rather likely that Brunetti knew Piquer as the long-serving royal physician; Piquer's 1764 medical textbook made

${ }^{49}$ Tomás de Iriarte, La música (Madrid: En la imprenta real de la Gazeta, 1779|, 9, 40, as translated in Tomás de Iriarte, Music: A Didactic Poem, in Five Cantos, trans. John Belfour (London: W. Miller, 1807), 48, 50. More broadly, the semitonal movement in two-part Phrygian cadences provided the archetypal association between semitones and melancholy affects, later compared to falling teardrops. public his hybrid coinage of "melancholicmanic" illness. ${ }^{50}$ By 1780 Brunetti (as well as other courtiers) might well have become aware of this new term because it specifically described the malady besetting the preceding Spanish kings according to their official physician. ${ }^{51}$ Yet Brunetti does not use this new term; indeed, he takes manía in a different direction than Piquer's melancholia-mania.

Contrary to its usual furious connotation, Brunetti's manía is not at all a frenzied outburst but rather a melancholy obsession characterized through a semitonal fragment. His program specifies that his symphony "describes (as far as possible, using only instruments and without the help of words) the fixation of a madman [maniático] on one sole purpose or idea. This role is given to the solo cello. Other instruments assume the roles of friends pledged to free him from his delusion, offering him an infinity of other ideas, in the form of

\footnotetext{
${ }^{50}$ Piquer, Praxis medica, 14-27.

${ }^{51}$ As argued by Georgallas, "The Maniac's Affliction," 9-11.
} 


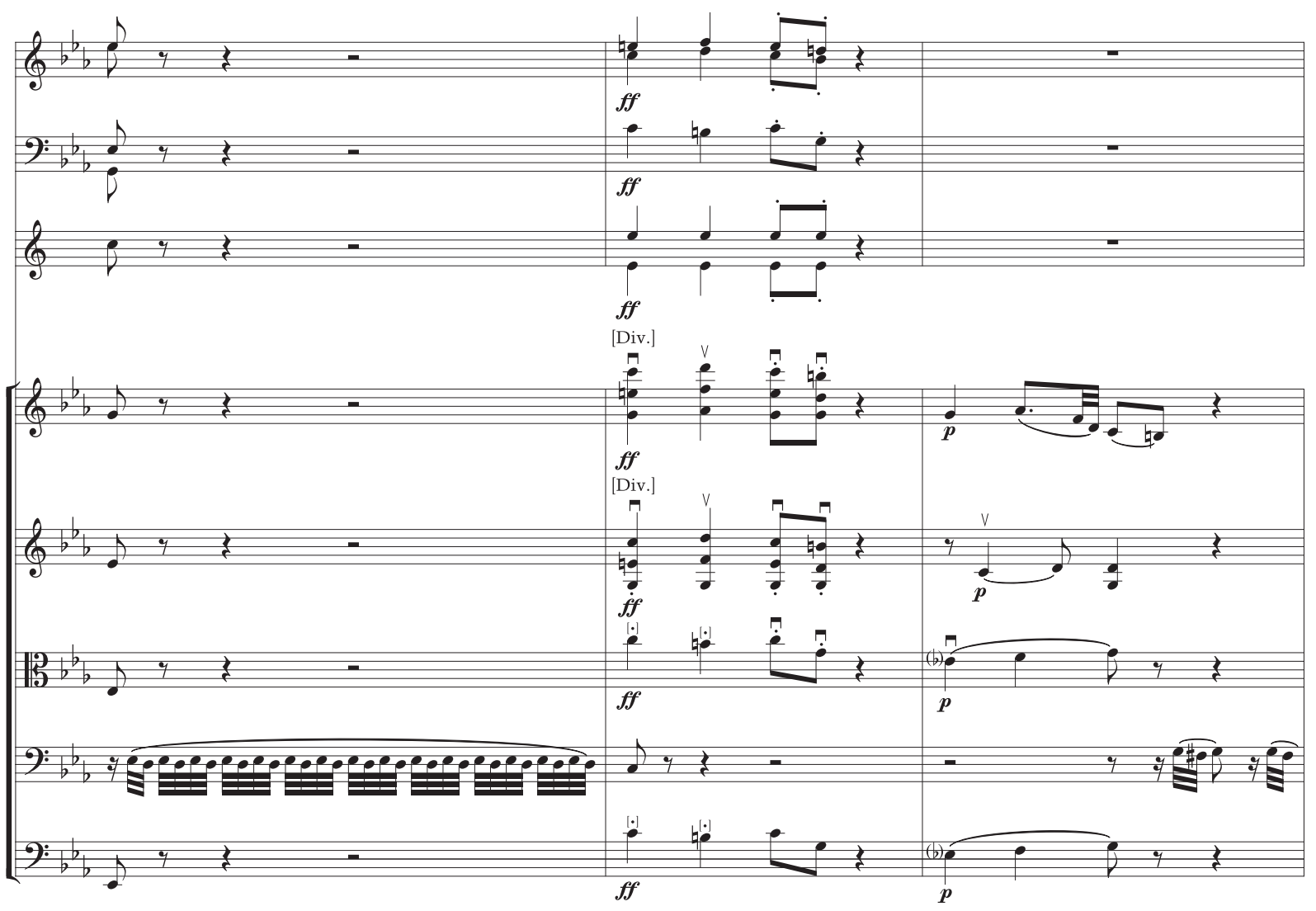

Example 3: The orchestra's outburst at mm. 43-45 of the first movement.

various musical motifs." ${ }^{\prime 52}$ The actual unfolding of this plan, however, includes quite a bit of dramatic interaction between the various instruments. Evidencing his awareness of contemporary symphonic style, the madman shapes his obsessive semitones to answer anything the orchestra can offer him. For its part, the orchestra seems to keep up the rather lyrical mood of this Andantino, as if good-naturedly trying to ignore the solo cello's obsessive repetitions. Still, at several moments the orchestra's patience seems to run out, leading to a fortissimo outburst of frustration, shown in ex. 3. As the Andantino unfolds, the orchestra alternates between such outbursts but more frequently reverts to "sensitive" passages that seem to humor the maniático. In the final measures of the Andantino, the strings take off their mutes

\footnotetext{
${ }^{52}$ Belgray, Gaetano Brunetti, xvi-xvii.
}

while the winds accompany the solo cello's continued obsessing, his mutterings marked più piano e morendo.

After a fermata general pause, the orchestra launches fortissimo into an Allegro in $\mathrm{Eb}$ major, as if to try the effect of this upbeat tonality and tempo. The maniático listens silently for seventy-five measures, evincing no reaction to this mostly triadic material. Well into the second group of its sonata form, a phrase with descending semitones moves him to respond with his obsession, expressed in the prevailing tempo and tonality (the dominant). The orchestra responds with a (seemingly exasperated) fortissimo, which does not deter the cello from repeating his phrase più forte and pizzicato; the orchestra redoubles its outburst but (not backing down) the maniático likewise repeats his fortissimo.

To this point, the orchestra and solo cello have generally alternated, but now both begin to overlay their heretofore separate utterances as the 


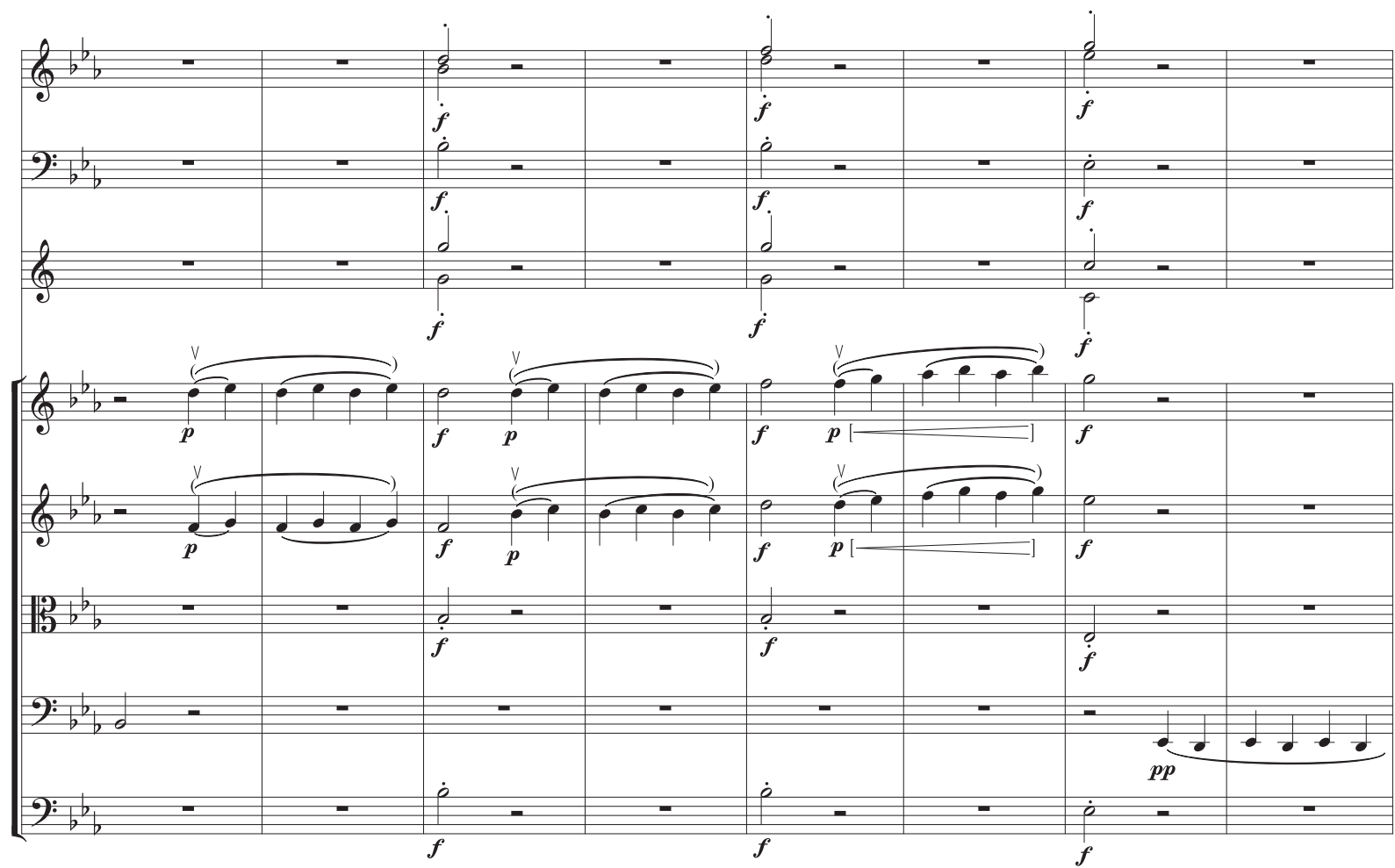

Example 4: The passage leading up to the recapitulation, the first violins presenting an inversion of the maniático's semitones.

maniático's obsessive semitones accompany the orchestra's lyrical second theme. This denotes a changed relation between them: the solo cello alone begins the development section by taking its obsession through a rising scale of semitones, as though self-consciously showing his awareness of the conventions of sonata form, using his obsession to begin the modulatory "tour of keys." In such a reading of the cello's agency, he even shows his lucidity by always conforming to the changing harmonies around him. On one hand, he still repeats the same semitonal obsession; on the other, he moves that gesture up and down the scale in such a way as to advance the developmental agenda. The orchestra even seems to appreciate this contribution, at one point even adopting a similar semitonal gesture.

Whether to humor the maniático or out of a more sincere appreciation for his efforts, the progression to the moment of recapitulation utilizes versions and inversions of his semitonal obsession (ex. 4). Though he would not have known this term, Brunetti's development section indicates alteration in the relation between maniático and orchestra, though it never really breaks the hold of his obsession. Afterwards, a kind of stand-off ensues; the recapitulation fastidiously repeats all the byplay of the exposition, but now in the tonic major. The movement ends on this inconclusive note after having briefly opened the possibility of some deeper rapport between the solitary obsessive and his orchestral milieu. Throughout, we can read this thematic byplay in terms of widely used procedures in contemporary composition alongside the programmatic and dramatic interpretation offered here, invited by the composer's own program. As we will see later, these two readings converge at the end of the work, in which Brunetti will emphasize the ironic similiarities between these musical conventions and the maniático's obsession.

The middle movement (Quintetto: Allegretto) begins with winds alone, still in $\mathrm{E} b$ major; the "Minore" uses only strings, in which the solo cello makes brief appearances $(\mathrm{mm} .8-11,14-18)$ relying 


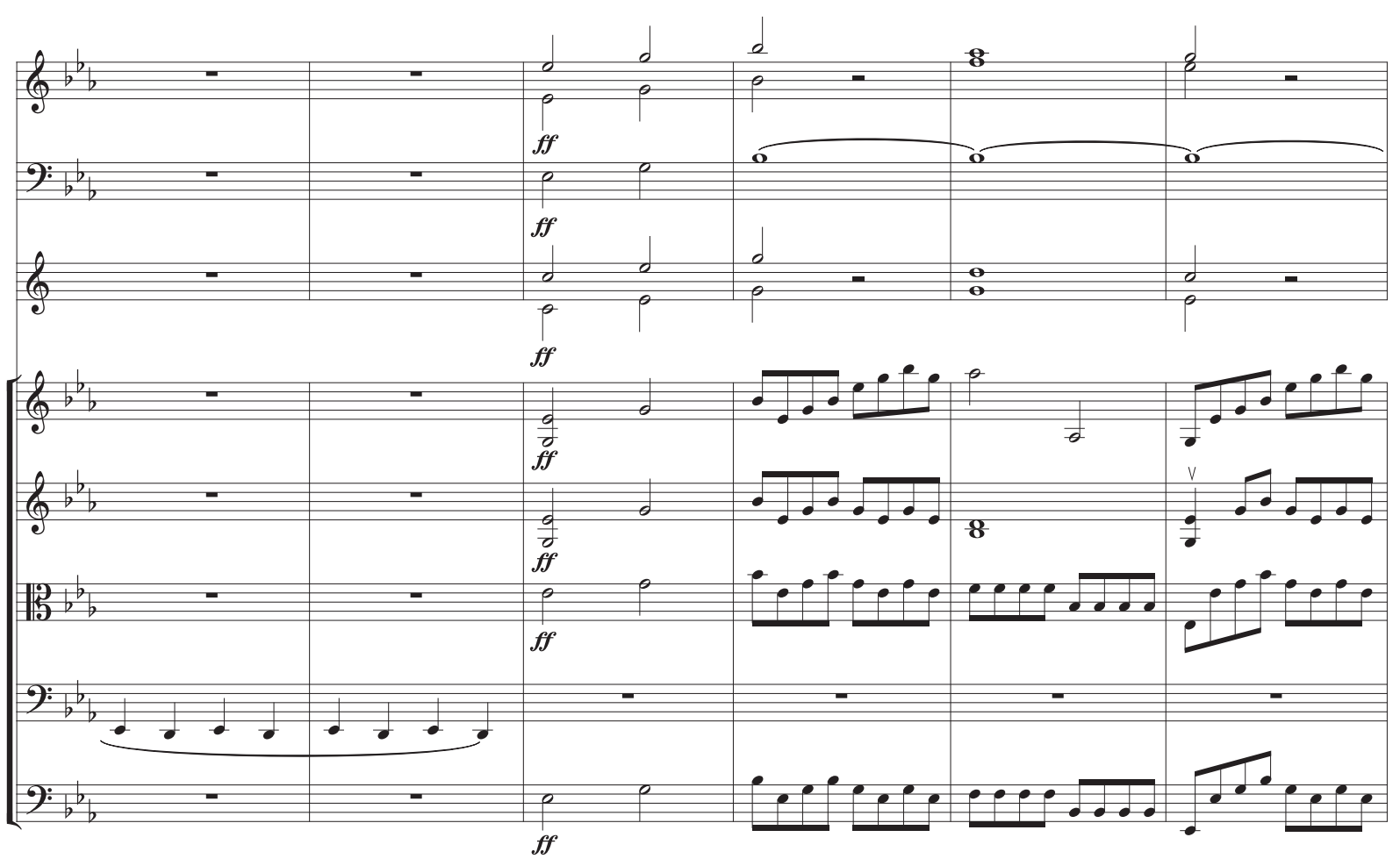

Example 4 (continued).

on his semitone, though he allows it to move upward at the very last minute (m. 18), shown in ex. 5. By comparison, Haydn never used monothematicism past a single movement. Though generally following his example, here Brunetti seems to take Haydn's practice even further in order to underline the extent of the maniático's obsession.

As ex. 6 shows, the final Allegro spiritoso seems to mark a decisive break that evidently corresponds to the next phase of Brunetti's program: "The maniático for some time clings to his original fancy, until he meets an allegro motif which attracts him, and he joins the others. ${ }^{\prime 53}$ For the first time, the maniático joins with the other celli in playing the same material, seemingly totally integrated with his peers. Though the movement's theme seems an unexceptionable example of the "brilliant" style, it retains aspects of obsession-perhaps calculated to be attractive to the maniático-by taking the initial semitone trill and transforming it into a diatonic

\footnotetext{
${ }^{53}$ Ibid., xvii.
}

descending motif, thrice repeated (ex. 7, p. 80). ${ }^{54}$ He continues to play this highly repetitive material with the other celli throughout most of the movement, occasionally stepping forward for brief solo appearances. But as ex. 8, see p. 81 shows, at the very end of the movement, one of these solos merges back into his initial obsession, the orchestra falls silent and even the metric pulse fails, marked ad libitum, senza rigore di tempo. As Brunetti's program specified: "soon he falls back into his previous manner." The maniático has relapsed, his initial obsession reasserting itself above his participation in the orchestral whole.

The orchestra now resumes the muted Andantino in $\mathrm{C}$ minor that preceded the maniático's obsession in the opening movement. Aside from its status as a quasi-cyclical form, one could read this as a mournful recognition of his relapse but also as a way the orchestra joins him in that relapse by recalling its part in

\footnotetext{
${ }^{54}$ See Roman Ivanovitch, "The Brilliant Style," in The Oxford Handbook of Topic Theory, 330-54.
} 

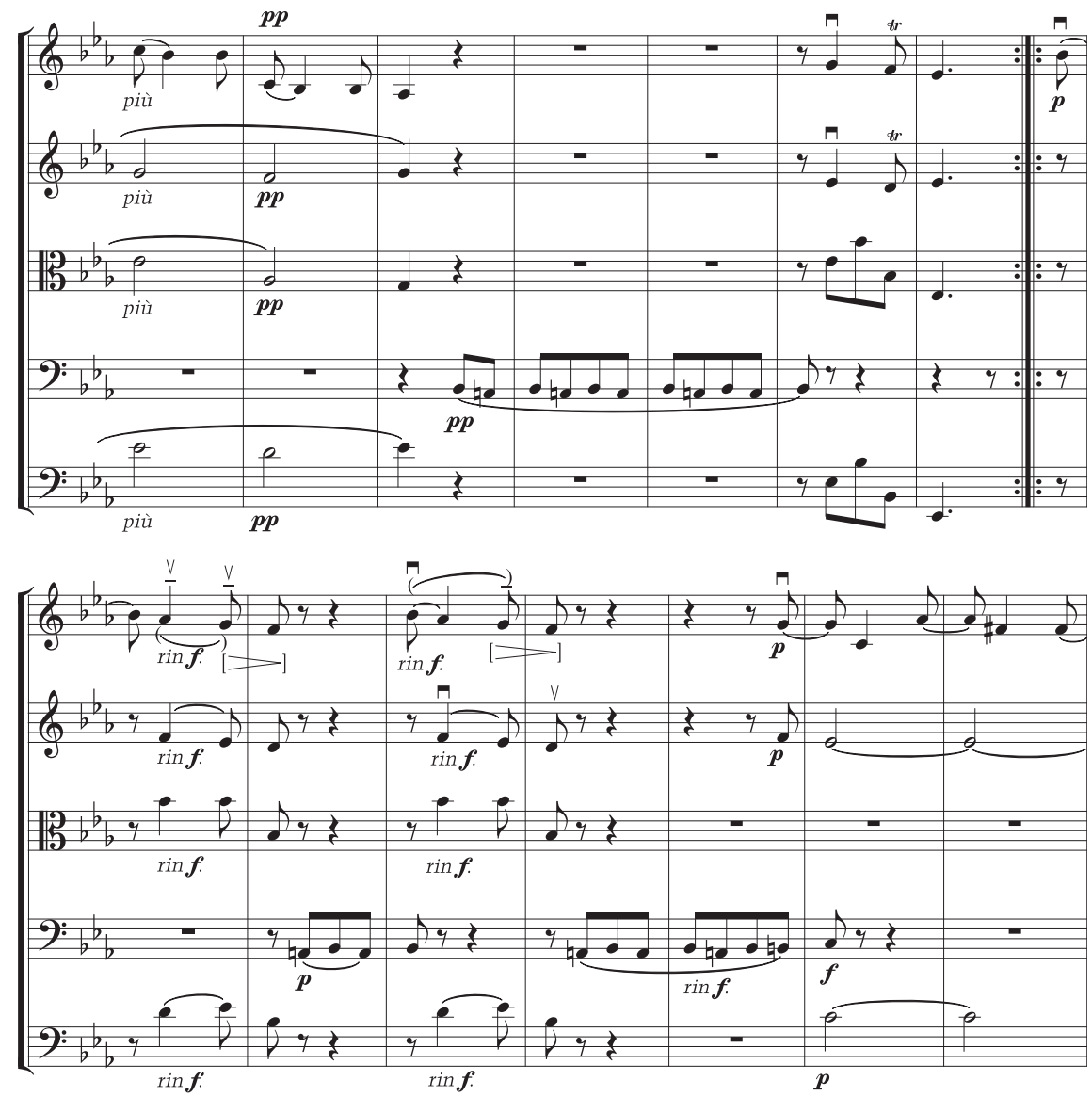

Example 5: Measures 6-19 of the Minore section of the second movement, showing the maniático's slightly varied semitones (m. 18).

its causation. Though this reprise closely follows the original Andantino, it ends on the dominant of $\mathrm{C}$, rather than the original dominant of $\mathrm{E} b$. The concluding Allegro spiritoso is in $\mathrm{C}$ major, the first time the symphony has moved away from $\mathrm{E} b$ and $\mathrm{C}$ minor, though only so far as to its parallel major. This turn to $\mathrm{C}$ major corresponds to the final phase of Brunetti's program: "At last, swept along by the general feeling, he ends with the others quite happily." ${ }^{55}$ Indeed, the solo cello now joins in the exuberant texture, at times soaring above the other celli to join the violins, at times playing along with their tutti. To be sure, these key relations fall within conventions widely shared by contemporary

\footnotetext{
${ }^{55}$ Brunetti, Il "maniático": Sinfonia no. 33, xvii (Italian text on xiii).
}

composers; I now reconsider the status of such conventions in light of the satirical context of this symphony.

Though Brunetti's program does not mention it, in the midst of this general rejoicing the strings launch into an extended unison repetition of the maniático's obsession, which the solo cello and winds accompany with jaunty eighth notes (ex. 8 , see p. 81). The obsessive gesture, it seems, is here exalted, practically canonized. One might read this as the orchestra mocking the obsession after it has finally been dispelled. Yet, given the maniac's history of relapse and the orchestra's repeated experience of having triggered those relapses, I think it more likely that the orchestra itself has been overtaken by the obsession, now not in a melancholic but a jubilant form, while the solo cello (seconded by the winds) stands back and enjoys it. Indeed, 

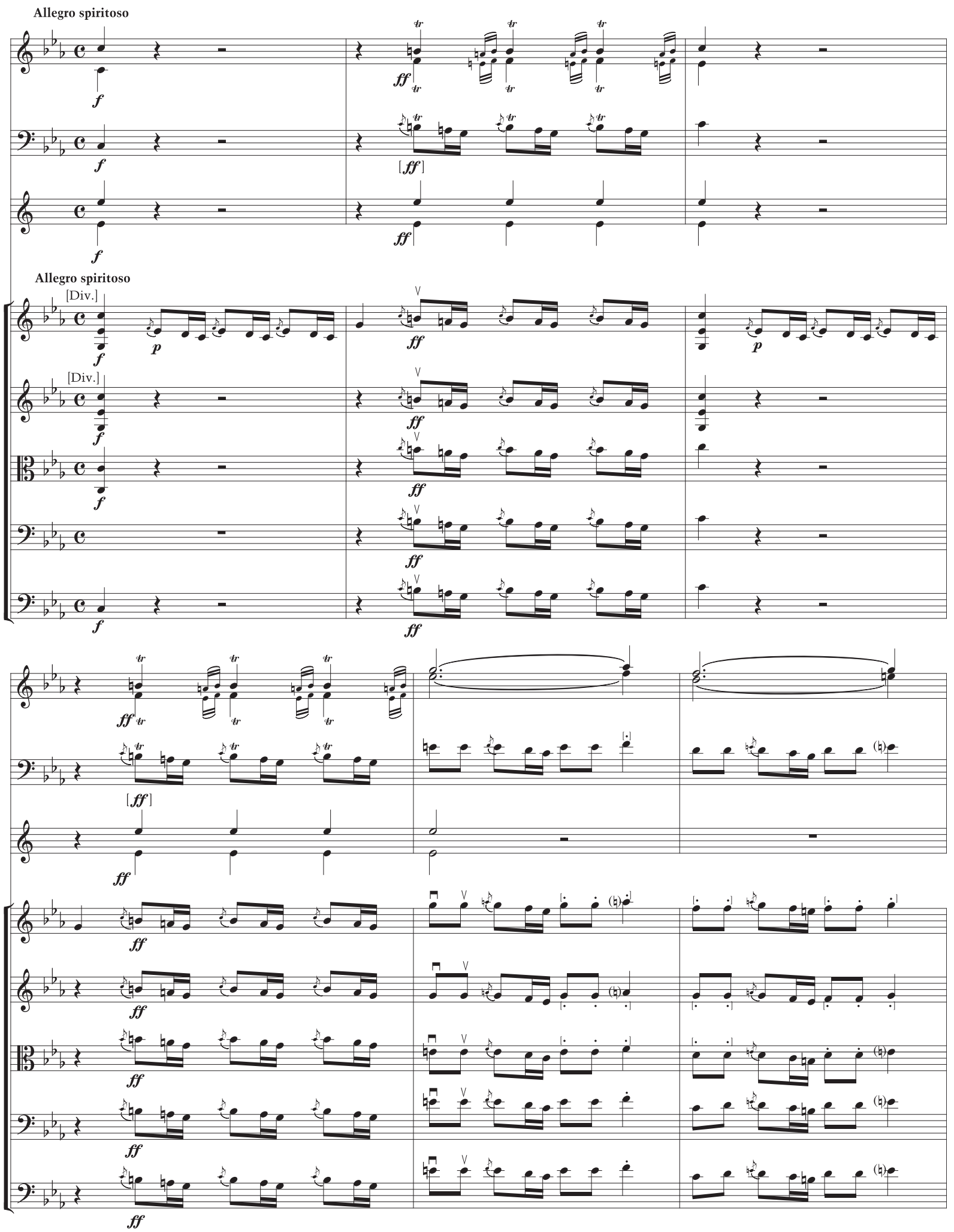

Example 6: The first six measures of the Allegro spiritoso. 


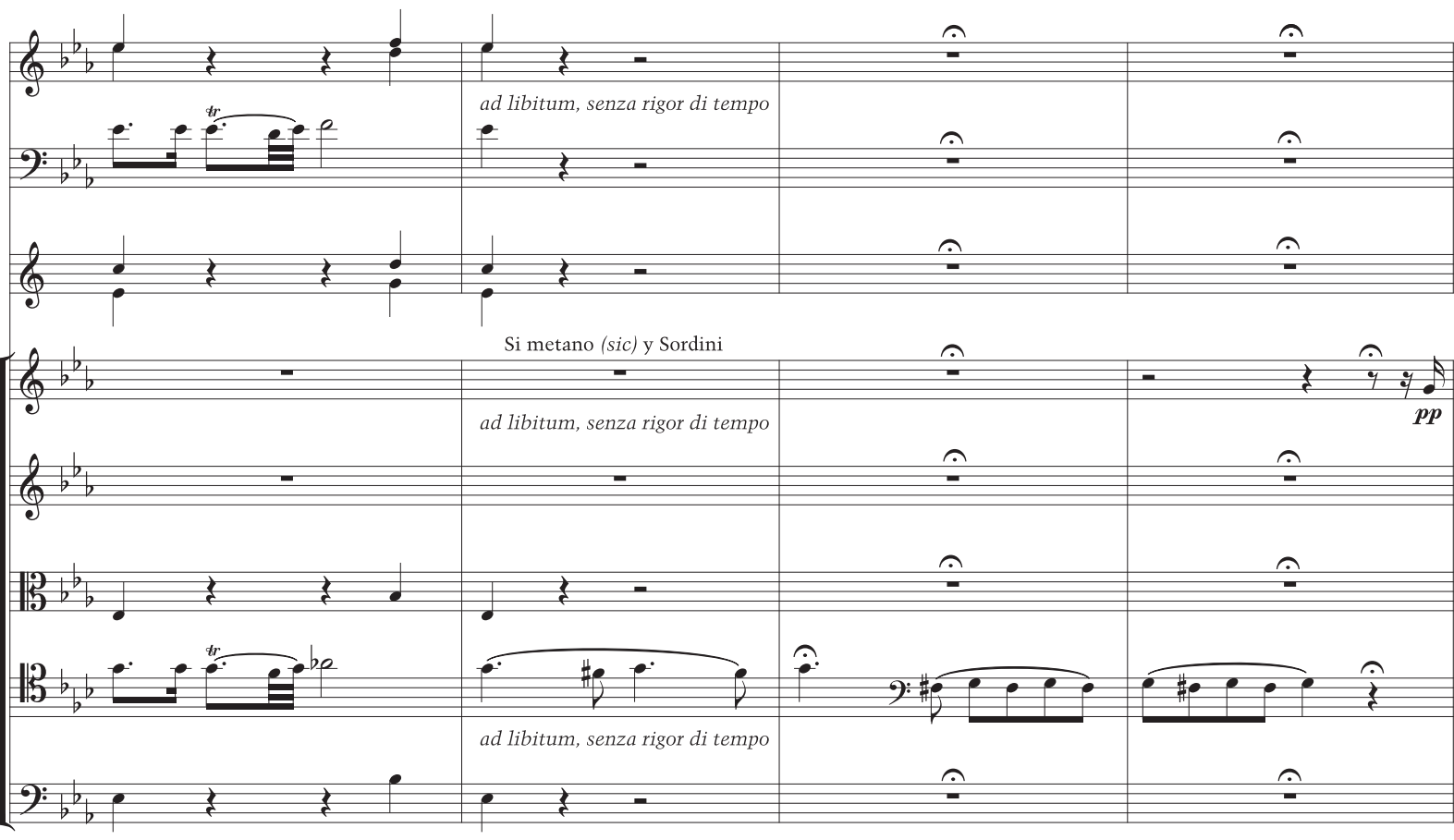

ad libitum, senza rigor di tempo

Example 7: Measures 73-76 of the Allegro spiritoso, the "relapse" just before the return of the Andantino.

the orchestra had indulged in various forms of the "obsessive" semitone trill many previous times but less consciously, using such repeated motifs as part of the conventional style or perhaps as a stratagem to allure the maniático. In its musical intercourse with him, the orchestra has seemingly awakened and acceded with good humor to the obsessional quality of its own common practice, to the classical style's notable dependence on repetition of simple motives.

\section{The Meaning of Mania}

Within Prince Carlos's circle, the maniático may have alluded to a well-known figure, the cellist and composer Luigi Boccherini. There is some evidence that Boccherini stood apart from the prince's court and from Brunetti. ${ }^{56}$ Boccherini

\footnotetext{
${ }^{56}$ Belgray, Gaetano Brunetti, 97-105, points out that several accounts of the enmity between Boccherini and Brunetti lack any documentary foundation so that "it is difficult to fathom the origin or determine the truth of the story."
}

(who arrived a few years after Brunetti) served in a rival aristocratic circle that surrounded Prince Carlos's uncle, Don Infante Luis (who had strong claims to the throne held by his brother, Carlos III, who treated him with marked care and respect). Further, an anecdote recounted by Alfredo Boccherini (the composer's greatgrandson) indicates Prince Carlos's irritation with Boccherini precisely on the issue of obsessional musical motifs. One day, Prince Carlos expressed the desire to hear Boccherini's latest quartets:

The prince took up his bow, with the intention of playing the part allotted to the first violin. This part consisted of a series of supremely monotonous bars, the notes do, si, do, si.

Utterly exasperated, he rose to his feet and said angrily: "This is abominable! Any beginner could write stuff like this! Do, si, do, si!"

"Sire," replied Boccherini, "will Your Highness graciously pay attention to the modulations that the second violin and the viola are executing, and to the pizzicato that may be heard in the part of the cello while the first violin repeats itself. The 

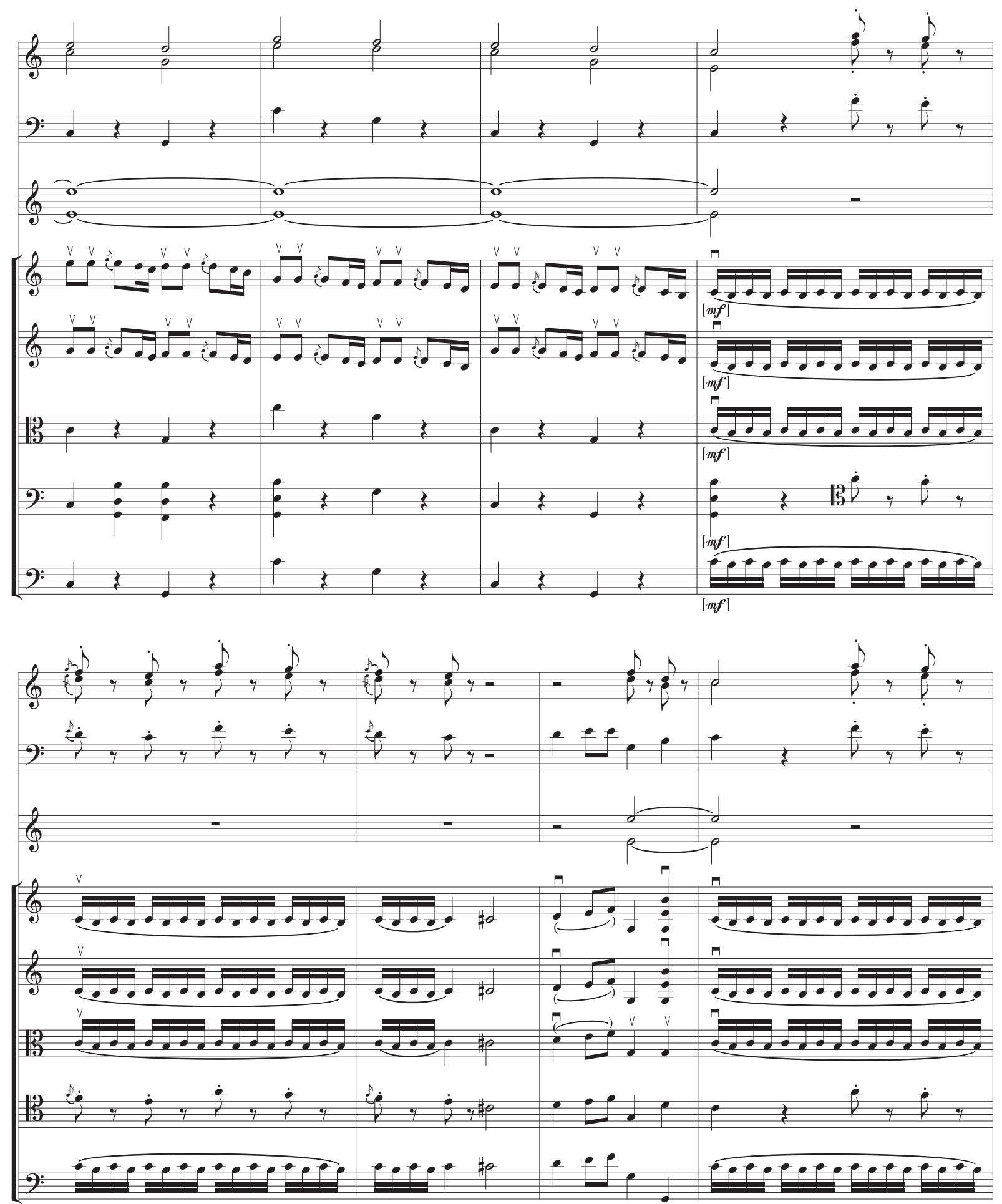

Example 8: Measures 9-16 of the final Allegro spiritoso, showing the orchestra playing the manía theme. 
uniformity of the first violin ceases to be monotonous the moment the other instruments enter and take part in the dialogue."

"Do, si, do, si! And it goes on like that for a half an hour. A delicious dialogue indeed! It is the music of a beginner and of a bad beginner!"

"Sire, before pronouncing such a judgment it is necessary to understand music." ${ }^{17}$

According to one of Boccherini's biographers, this cutting retort led to his being excluded from Prince Carlos's palace, where not even his name was to be mentioned. ${ }^{58}$ Nor was this exceptional: other stories relate Boccherini's prickly behavior in defense of his compositional practices. ${ }^{59}$

Prince Carlos's ill-tempered comment probably touched a sore point: Boccherini's penchant for repetition. Indeed, Rudolf Rasch judged that, among classical composers, Boccherini's "works make the most abundant use of repetition procedures." 60 Though the exact work that irritated the prince eludes identification, in one candidate (the third movement of the Quintet op. 28, no. 2, G. 308, 1779/ the second violin and viola remain stuck on do for almost the whole movement, occasionally interspersed with si, while the cello is allowed a virtuosic flight at the movement's close. ${ }^{61}$ A celebrated virtuoso on that instrument, Boccherini was closely identified with the cello, which he often used soloistically in his chamber music. Regardless of whatever may have been the composition in question, Brunetti's symphony can plausibly be read as a satire on Boccherini by

\footnotetext{
${ }^{57}$ Germaine de Rothschild, Luigi Boccherini: His Life and Work, trans. Andreas Mayor (London: Oxford University Press, 1965), 39-40. The translation has been slightly adjusted to follow the orthography of the Spanish original, given in Nicolás Solar-Quintes, "Nuevos documentos sobre Luigi Boccherini," Anuario Musical 2 (1947): 81.

${ }^{58}$ Rothschild, Boccherini, 40, however without giving further evidence for this assertion.

${ }^{59}$ Belgray, Gaetano Brunetti, 103.

${ }^{60}$ Rudolf Rasch, "The Art of Repetition as Practiced by Luigi Boccherini in His Sonatas for Keyboard and Violin Opus 5," in Boccherini Studies, ed. Christian Speck, vol. 4 (Bologna: Ut Orpheus Edizioni, 2014), 291.

${ }^{61}$ This is the candidate of Yves Gérard, Thematic, Bibliographical, and Critical Catalogue of the Works of Luigi Boccherini (London: Oxford University Press, 1969), 346, though Elisabeth Le Guin, Boccherini's Body: An Essay in Carnal Musicology (Berkeley: University of California Press, 2006), 69, judges that "the quintet referred to here cannot be identified."
}

making his chosen instrument the voice of the maniático, whose obsessional do si do si fits the tenor of the story and surely would have amused the prince.

In addition, within the context of Prince Carlos's circle Brunetti's symphony also offered a mirror to the various forms of royal insanity that had plagued the preceding reigns. Though far less subject to "mania-melancholia" than his predecessors Felipe V and Fernando VI, Carlos III was somewhat melancholic, to which his obsessive regularity seemed to have offered a kind of counterbalance. Though there was considerable tension between them, any open mockery of the king before Prince Carlos would have been out of the question. Still, Prince Carlos may have appreciated a veiled satire on his father's obsessiveness, especially expressed in music, an art to which he was devoted, despite (or perhaps because of) his father's aversion. Having served as his violin teacher for thirteen years, Brunetti was a familiar and well-accepted figure; every known detail of Prince Carlos's relation to him suggests their sympathy. In the stormy days of 1780, this symphony's gentle but pointed picture of obsessiveness may well have lightened the prince's mood. At the Spanish court, instrumental music was allowed a degree and kind of dramatic mimicry that would scarcely have been permitted in a texted work.

As the analysis above has pointed out, Brunetti's symphony goes far beyond a parody of obsession to give a more complex picture of the maniático as deeply embedded in his social context (not merely an isolated figure), while also reflexively critiquing aspects of the prevailing symphonic style. Brunetti presents obsession as both emerging from yet coping with melancholy. Though there is a certain pathos in the maniático's mournful repetitions, Brunetti also underlines the ways in which the maniático is able to accommodate to his surroundings, both maintaining his obsession while reshaping it to fit its surrounding harmonic context. By alternately humoring him and trying to shake him into normalcy, the orchestra undertakes a certain effort of compassion that (in my reading) ultimately becomes a kind of self-recognition: the maniático's private obsession turns out to be a part of a larger tissue of obsession that 
marks the whole stylistic world all the instruments inhabit together.

Thus, compared to earlier accounts of this symphony, the present reading undercuts straightforward versions of the maniático's "cure" in favor of a far more ironic interpretation. $^{62}$ Prince Carlos may have savored this irony: the singular maniático at the center of the composition (perhaps standing for the king or even the prince himself) is finally reconciled to his world through a universal realization of the obsessionality-even the madness-of their shared world. Though Pedro Caldéron de la Barca's reputation by then had faded somewhat in Spain, one wonders whether the prince identified himself with the crown prince Segismondo, protagonist of La vida es sueño (Life is a Dream, 1635), imprisoned and tormented by his father through illusory scenes of reconciliation. Brunetti's symphony could likewise have held up a mirror to the disturbed mental states and relationships known to father and son. Even more, it seems likely that Spanish listeners to this tale of obsession and melancholia would have thought of Don Quixote, the famous "knight of the melancholy countenance."

\section{The Changing Status of Obsession}

Apart from such topical references, Brunetti's symphony presents a careful musical rendition of the phenomenology of obsession, an unusual (perhaps even unique) example of a mental condition being anatomized musically before being described clinically. I have argued that Brunetti does not present musically as simple and triumphant a narrative of cure as his program might suggest (and as its interpreters have heretofore assumed). His premise is deeply social: the maniático can only be understood in terms of his environing musical world, in which he participates even through his obsession. In the manuscript layout, his line stands next to the other celli, not apart from them, as became the convention for concertos. The maniático's obsession

\footnotetext{
${ }^{62}$ Compare Howe, "Music and the Agents of Obsession"; Georgallas, "The Maniac's Affliction," reads the symphony in terms of mania-melancholia (bipolar disorder).
}

ultimately reflects the stylistic practices of his time, which his story brings to consciousness, first of all to the orchestra's awareness and thereby to the listeners as well. The larger irony is that the whole orchestra (and the world it represents) is obsessed no less than the maniático himself. Brunetti shows his obsessions as congruent with (and responsive to) the orchestra around him. At first, the orchestra treats the maniático as irrelevantly repetitious but in the course of the development gradually involves itself in his material in service of what increasingly seems a shared endeavor. Such an irony would have been familiar to its courtly listeners, reared on Don Quixote, in which successively more and more characters (including a duke and duchess) come to be obsessed with the melancholy knight, in the process becoming (as Cervantes noted) madder than Quixote himself. ${ }^{63}$

In contrast to this complex social dialogue, Berlioz imposed his idée fixe far more straightforwardly over his musical world. Though the Symphonie fantastique has often been taken as the exemplar of musical discourse on obsession, I will conclude by suggesting that Berlioz was not interested in giving a medical portrait of idée fixe except as a heightened way to project his own story and intensify his symphony. The self-conscious and solipsistic quality of his symphony might be called "secondary" to the phenomena of idée fixe, compared to the "primary" and ironic approach of Brunetti's symphony (which Berlioz could scarcely have known). I will conclude by clarifying the development of idée fixe that lay between Brunetti and Berlioz, particularly the relative roles of medical and literary discourse. $^{64}$

Francesca Brittan has insightfully underlined the possible influence of contemporary interest in monomania on Berlioz's conception, emphasizing Esquirol's theorization in the 1810s, culminating in his 1819 paper defining monomania. ${ }^{65}$ She seems to follow Jan Goldstein's opinion that idée fixe was "originally a medical term, probably coined by the phrenologists Franz Josef Gall and Johann Spurzheim in connection with Esquirol's

\footnotetext{
${ }^{63}$ Cervantes, Don Quijote, 614.

${ }^{64}$ See also Howe, "Music and the Agents of Obsession."

${ }^{65}$ Brittan, "Berlioz and the Pathological Fantastic," 220.
} 
delineation of monomania." 66 There were, however, a considerable number of literary references to idée fixe decades before Esquirol.

Though a French term, the earliest usages of idée fixe to denote an obsessive idea came not in French but in other languages. During the eighteenth century, idée fixe in French meant a specific or determined idea, "fixed" only in the sense of being definite but without any connotation of obsession; the earliest usage of idée fixe in French in that sense dates from about $1813 .{ }^{67}$ On the other hand, fixe Idee is found in earlier German sources with the clear meaning of obsessional ideation. The phrase appears thus in German periodicals by $1785 .^{68}$ Jean Paul used fixe Idee in a letter of 1789; his novel Hesperus (1794) describes a madman who "carried around the fixed idea [die fixe Idee] that Death was after him and wanted to seize and abduct him by the left hand, which he therefore concealed." ${ }^{69}$ His widely read novel Titan (1802) also used this phrase, which his protegé E. T. A. Hoffmann also used in his stories. ${ }^{70}$ But it was Johann Christian Reil's Rhapsodieen über die Anwendung der psychischen Curmethode auf Geisteszerrüttungen (1803) that really took up fixe Idee as an important concept in the new discipline of what in 1808 he named "psychiaterie," of which he held one of the first university professorships. ${ }^{71}$ During this period, Reil was also in conversation with Goethe about his new ideas about psychiatric medicine, ideas that were percolating far and wide; Goethe too began to use

${ }^{66}$ Jan Goldstein, Console and Classify: The French Psychiatric Profession in the Nineteenth Century: With a New Afterword (Chicago: University of Chicago Press, 2001), 155, which refers to the use of idée fixe by Franz Joseph Gall and Johann Spurzheim, Anatomie et physiologie du systême nerveux en général, et du cerveau en particulier (Paris: F. Schoell, 1812), 2:20, 192.

${ }^{67}$ From a search on "ARTFL FRANTEXT," accessed 29 May 2018, https://artflsrv03-uchicago-edu.ezp-prodl.hul.harvard. edu/philologic4/frantext0917/query? report=concordance \& method=proxy\&q=id\%C3\%A9e\% 20fixe \&start=0\&end $=0$.

${ }^{68}$ See Allgemeine Literatur-Zeitung (1785): 43, 493.

${ }^{69}$ Jean Paul, Sämtliche Werke (Munich: Carl Hanser Verlag, 1996), III/1:271 (see also III/4:387 and I/1:1128).

${ }^{70}$ Ibid., I/3:700, 777. For their relation, see Robert Herndon Fife, "Jean Paul Friedrich Richter and E. T. A. Hoffmann," PMLA 22, no. 1 (1907): 1-32.

${ }^{71}$ Johann Christian Reil, Rhapsodieen über die Anwendung der psychischen Curmethode auf Geisteszerrüttungen (Halle: Curt, 1803), discussed in Matthew Bell, The German Tradition of Psychology in Literature and Thought, 17001840 (Cambridge: Cambridge University Press, 2005), 166-201. the expression idée fixe about $1810 .^{72}$ In De l'Allemagne (1810), Madame de Staël described her decision "to make known the genius of Jean Paul" by translating him; through her and others, Jean Paul's work (and terminology) became known to the French public, presumably including idée fixe (as his term was rendered). ${ }^{73}$ Among medical writers, Gall and Spurzheim (1812) referred to Reil's work, as did Esquirol himself. ${ }^{74}$ Thus, though these French writers and alienists do not explicitly acknowledge it, it seems likely that their use of idée fixe reflects earlier sources in other literary traditions.

The significance of this chronology is that the concepts of idée fixe and (by implication) monomania ultimately come from literary rather than purely medical sources, as has been the prevailing assumption. ${ }^{75}$ Among these literary sources, Don Quixote has special importance as the premier exemplar of idée fixe in the Western tradition whose immense influence across Europe rose during the eighteenth century. ${ }^{76}$ Indeed, Esquirol himself, in defining monomania and setting forth his case histories, noted that "one finds in Don Quixote an admirable description of monomania, which reigned over almost all of Europe after the Crusades: a mixture of amorous extravagance with chivalrous bravura, which in many individuals was a real insanity [folie]."

This brings us back to our starting point and to Spain, where the first musical portrayal of obsession appeared after decades of royal insanity, in a

\footnotetext{
${ }^{72}$ Devin K. Binder, Karl Schaller, and Hans Clusmann, "The Seminal Contributions of Johann-Christian Reil to Anatomy, Physiology, and Psychiatry," Neurosurgery 61 (2007): 1091-96. ${ }^{73}$ Germaine de Staël-Holstein, De l'Allemagne (Paris: H. Nicolle, 1810), 285-86. For idée fixe, see Jean Paul, Titan, trans. Philarète Chasles (Paris: Abel Ledoux, 1834), IV, 36, 37, 194, 200.

${ }^{74}$ Gall and Spurzheim, Anatomie et physiologie, II, 218, 356 , 379; Étienne Esquirol, Des maladies mentales: considérées sous les rapports médical, hygiénique et médico-légal (Paris: J. B. Baillière, 1838), I, 126, 219, 521; II, 359, 401, 530. ${ }^{75}$ Indeed, in the letters delineating his program Berlioz alludes directly to Chateaubriand's "vagues de passion," but not to the medical works Brittan suggests, as well as to Shakespeare, who (rather than Harriet Smithson) may well have been the source of Berlioz's own obsessions.

${ }^{76}$ See Manuel Durán and Fay R. Rogg, Fighting Windmills: Encounters with Don Quixote (New Haven, CT: Yale University Press, 2006).

${ }^{77}$ Esquirol, Des maladies mentales, II, 28-29.
} 
court ruled by an obsessive monarch in the land of Quixote. Overall, literary and musical depictions of obsession preceded and prepared its clinical description, which (as with Esquirol himself) sometimes indicated their indebtedness to the artistic originals that illuminated so many maladies. Thus, Cervantes's novel has incomparable importance for later attempts to understand Quixote's condition as it was refracted into other, more quotidian instances. Yet Brunetti's symphony, so long forgotten, added significantly to the description and understanding of manía precisely because it could give an entirely newmusical-form to what had previously only been expressed in words.

\section{Abstract.}

In his symphony "Il maníatico" (1780), Gaetano Brunetti gave a musical portrayal of monomania decades before it became a staple of nineteenthcentury alienism (psychiatry), as well as of Romantic music and art. A detailed analysis of his symphony shows both the presenting features of what he called manía as well as the stages of the "maniac's" interaction with the surrounding "normal" world. These stages respond to widely known mental peculiarities of several generations of Spanish royalty, whom Brunetti served as court composer. Though its court audience would likely have compared this portrayal of obsession to Cervantes's Don Quixote, Brunetti's symphony may also have sent a coded message of sympathy to his patron, the crown prince who would later reign as Carlos IV and who struggled with his obsessional father, then reigning as Carlos III. At the same time, Brunetti mocked Luigi Boccherini, his rival as court composer. By presenting a subversive reimagining of the "normal" symphonic world, Brunetti characterized the mannerisms of classical style as monomania writ large. In the following decades, the term fixe Idee emerged in German literature and usage considerably before the French idée fixe. Both concepts emerged from literary, rather than medical, sources. Though Don Quixote remained a touchstone for reflections on "madness," Brunetti's symphony anatomized obsession decades before medical discourse gave its clinical description. 